\title{
Contents of soil organic carbon and nitrogen in water-stable aggregates in abandoned agricultural lands in an arid ecosystem of Northwest China
}

\author{
WANG Junqiang ${ }^{1,2 *}$, LIU Lichao ${ }^{1}$, QIU Xiaoqing ${ }^{3}$, WEI Yujie ${ }^{2}$, LI Yanrong ${ }^{2}$, SHI Zhiguo ${ }^{2}$ \\ ${ }^{1}$ Cold and Arid Regions Environmental and Engineering Research Institute, Chinese Academy of Sciences, Lanzhou 730000, \\ China; \\ ${ }^{2}$ Gansu Academy of Agricultural Engineering and Technology, Wuwei 733006, China; \\ ${ }^{3}$ Gansu Polytechnic College of Animal Husbandry \& Engineering, Wuwei 733006, China
}

\begin{abstract}
Soil organic matter content in water-stable aggregates (WSA) in the arid ecosystems (abandoned agricultural lands especially) of China is poorly understood. In this study, we examined the WSA sizes and stability, and soil organic carbon (OC) and nitrogen (N) contents in agricultural lands with abandonment ages of $0,3,12,20,30$ and 40 years, respectively, in the Minqin Oasis of Northwest China. The total soil OC and $\mathrm{N}$ contents at depths of $0-20,20-40$ and $40-60 \mathrm{~cm}$ in abandoned agricultural lands were compared to those in cultivated land (the control). Agricultural land abandonment significantly $(P<0.05)$ influenced the distribution of MWD (mean weight diameter), and $\mathrm{OC}$ and $\mathrm{N}$ contents. There were significant increases in MWD and the proportion of macroaggregates (sizes $>0.25 \mathrm{~mm}$ ) as the age of agricultural land abandonment increased. The effect of abandonment ages of agricultural lands on MWD was determined by the changes of OC and $\mathrm{N}$ accumulation in WSA sizes $>2 \mathrm{~mm}$. The total $\mathrm{OC}$ and $\mathrm{N}$ contents presented a stratification phenomenon across soil depths in this arid ecosystem. That is, both of them decreased significantly at depths of $0-20$ and $40-60 \mathrm{~cm}$ while increased at the depth of $20-40 \mathrm{~cm}$. The WSA sizes $<0.053$ $\mathrm{mm}$ had the highest soil OC and $\mathrm{N}$ contents (accounting for $51.41 \%-55.59 \%$ and $42.61 \%-48.94 \%$ of their total, respectively). Soil $\mathrm{OC}$ and $\mathrm{N}$ contents in microaggregates (sizes $0.053-0.25 \mathrm{~mm}$ ) were the dominant factors that influenced the variations of total $O C$ and $N$ contents in abandoned agricultural lands. The results of this study suggested that agricultural land abandonment may result in the recovery of WSA stability and the shifting of soil organic matter from the silt+clay $(<0.053 \mathrm{~mm})$ and microaggregate fractions to the macroaggregate fractions. However, agricultural land abandonment did not increase total soil $\mathrm{OC}$ and $\mathrm{N}$ contents in the short-term.
\end{abstract}

Keywords: aggregate stability; water-stable aggregates; agricultural abandonment; soil organic carbon; total nitrogen; northwestern China

Citation: WANG Junqiang, LIU Lichao, QIU Xiaoqing, WEI Yujie, LI Yanrong, SHI Zhiguo. 2016. Contents of soil organic carbon and nitrogen in water-stable aggregates in abandoned agricultural lands in an arid ecosystem of Northwest China. Journal of Arid Land, 8(3): 350-363. doi: 10.1007/s40333-016-0042-7

The relationship of soil aggregate characteristics with soil organic carbon (OC) and nitrogen (N) has been reported extensively (Six et al., 2000a; Lützow et al., 2006). The concept of aggregation involving different organic binding agents at different scales was pioneered by Tisdall and Oades (1982). Subsequently, Waters and Oades (1991) introduced the concept of aggregate hierarchy and provided that organic matter is key to soil aggregate stability, and in turn is affected by aggregate

*Corresponding author: WANG Junqiang (E-mail: wangjunq0303@163.com)

Received 2015-06-23; revised 2015-10-26; accepted 2015-12-23

(C) Xinjiang Institute of Ecology and Geography, Chinese Academy of Sciences, Science Press and Springer-Verlag Berlin Heidelberg 2016 
destabilization and turnover rate (Zagal et al., 2013). Determining OC pools in aggregates can provide important information on soil OC sequestration and mineralization in aggregate size fractions, and aggregate stability can be protected by using appropriate soil and crop management practices (Whalen and Chang, 2002).

Water-stable aggregates (WSA) are the foundation of both water and fertility conservation (Sui et al., 2012). Soil aggregate stability is influenced by land use change (e.g. agricultural abandonment) in the way that changes the proportion of WSA sizes (John et al., 2005; Ashagrie et al., 2007) and mean weight diameter (MWD) (Bonifacio et al., 2006). Microaggregates, however, seem to be less influenced by land use change (Puget et al., 2000). WSA and MWD fractions increase with increasing organic matter content (Onweremadu et al., 2007). Carter (1996) and Haynes (2000) noted that soil OC content is often associated with WSA percentage and macroaggregate stability. Jastrow (1996) observed that macroaggregate formation occurs first and develops rapidly in soil. Therefore, WSA and MWD can be used as indicators for evaluting the influence of land use change (e.g. agricultural land abandonment) on soil quality (Sui et al., 2012). Thus, accurate evaluation of the effects of land use change (e.g. agricultural abandonment) on soil OC and N contents is required to monitor the WSA and MWD dynamics.

Soils with higher WSA percentage and MWD often have high OC and N contents because such soils are likely to have greater resistance to degradation and erosion (Celik, 2005; Onweremadu et al., 2007). When agricultural abandonment occurs, soil properties such as organic matter content, structure and infiltration rate may be improved, resulting in more effective protection against soil erosion (Kosmas et al., 2000). These results may benefit soil evolution. Investigating the soil OC after agricultural land abandonment, as expressed in OC content in different size fractions of WSA is more crucial than studying the overall soil OC, because it leads to an improved understanding of soil OC dynamics. Thus, studies are needed on the influence of agricultural land abandonment on aggregate-associated soil OC representing the soil OC pool with different aggregate stabilities, especially in degraded soils with poor soil structure, low OC and $\mathrm{N}$ content, and compacted layers in semi-arid regions (Wiesmeier et al., 2012).

Recently, extensive areas of cultivated land have been abandoned in many countries worldwide (Cramer et al., 2008; Prishchepov et al., 2012; Six and Paustian, 2014). This phenomenon also happened in the interior northwestern provinces of China as a result of environmental degradation as well as economic and social changes (Yang and Li, 2000; Jin et al., 2008; Deng et al., 2013; Zhang et al., 2014). To date, studies on soil OC or N and WSA in abandoned agricultural lands focus either on the dynamics of soil OC pools or the changes of WSA (Novara et al., 2014; Gabarrón-Galeote et al., 2015). Limited information is available on the long-term changes of WSA stability and OC in different WSA sizes at different soil depths of abandoned agricultural lands, especially in Northwest China. Thus, the main objectives of this study were to: (1) characterize WSA fractions and stability in different soil layers; (2) determine the contents of OC and N within WSA at various soil depths; and (3) assess the dominant factors affecting soil OC, N and WSA stability after agricultural land abandonment.

The Minqin Oasis in Northwest China was selected as the study area because of the presence of different successional stages of abandoned agricultural lands and the existence of distinct vegetation patterns as a result of arid climate. This study may be useful in identifying the mechanisms responsible for WSA formation and stability in relation to soil OC and $\mathrm{N}$ sequestration after cessation of cultivation. The study can also enhance the understanding of the role played by soil spontaneous recovery ability in abandoned agricultural lands in arid regions, which is crucial to environmental quality and regional agricultural sustainability.

\section{Materials and methods}

\subsection{Study area}

The Minqin Oasis $\left(38^{\circ} 03^{\prime}-39^{\circ} 27^{\prime} \mathrm{N}, 101^{\circ} 49^{\prime}-104^{\circ} 12^{\prime} \mathrm{E}\right)$ is located in the Shiyang River basin of Gansu province, Northwest China. It has a land area of $159.107 \mathrm{~km}^{2}$ and a population of approximately 306,900. The elevation of the region ranges from 1,295 to 1,460 $\mathrm{m}$, with the terrain 
generally downward from southwest to northeast. The oasis is surrounded by the Badain Jaran Desert to the west and north and the Tengger Desert to the east. The area is characterized by an arid continental climate with an annual mean temperature of $7.8^{\circ} \mathrm{C}$ (average maximum of $23.2^{\circ} \mathrm{C}$ in July and average minimum of $-9.6^{\circ} \mathrm{C}$ in January). The mean annual precipitation is $110 \mathrm{~mm}$ with uneven distribution, but the annual potential evaporation exceeds 2,664 mm (Sun et al., 2006) because of the arid climate in the area. The Minqin Oasis is one of the most severely desertified regions in China, and the ecosystems of the oasis are extremely fragile.

In this study, the agricultural lands with abandonment ages of 0 (control, cultivated land), 3, 12, 20, 30 and 40 years with well-known land use history and current management practices were selected in the northeastern part of the Minqin Oasis within a radius of $6 \mathrm{~km}$. We used the historical records and aerial photos of the study area to determine the cultivation and management histories before and after land abandonment. The information and photos showed that all the abandoned and cultivated lands experienced similar tillage and cultivation practices in the cultivated years, and the lands were arable for many decades (Table 1).

All the studied lands have the same topography and soil type (anthropogenic alluvial soil), and the farming and tillage practices before abandonment were commonly conventional tillage with irrigation. Now, the abandoned lands are covered by natural vegetation and devoid of tree species. The selected lands were cultivated with mostly barley and cotton before abandonment and were kept fallow after abandonment.

Table 1 Cultivation time, dominant species and plowing methods in agricultural lands with different abandonment ages

\begin{tabular}{|c|c|c|c|}
\hline $\begin{array}{l}\text { Age of agricultural land } \\
\text { abandonment (a) }\end{array}$ & $\begin{array}{l}\text { Cultivation } \\
\text { time }\end{array}$ & Dominant species & Plowing method \\
\hline 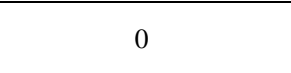 & $\begin{array}{l}1989 \text { to } \\
\text { present }\end{array}$ & $\begin{array}{l}\text { Hordeum vulgare, } \\
\text { Gossypium spp. }\end{array}$ & $\begin{array}{l}\text { Conventional ploughing in autumn and rotary tillage in } \\
\text { spring }\end{array}$ \\
\hline 3 & 1983-2009 & $\begin{array}{l}\text { Poa annua, } \\
\text { Suaeda glauca }\end{array}$ & $\begin{array}{l}\text { Conventional ploughing in autumn and rotary tillage in } \\
\text { spring before abandonment }\end{array}$ \\
\hline 12 & $1967-2000$ & $\begin{array}{l}\text { Halogeton glomeratus, } \\
\text { Achnatherum splendens }\end{array}$ & \\
\hline 20 & 1968-1992 & $\begin{array}{l}\text { Kalidium foliatum, } \\
\text { Salsola passerina }\end{array}$ & $\begin{array}{l}\text { Conventional ploughing in autumn before abandonment } \\
\text { and light grazing by sheep after abandonment }\end{array}$ \\
\hline 30 & 1957-1982 & $\begin{array}{l}\text { Nitraria sphaerocarpa, } \\
\text { Reaumuria songarica }\end{array}$ & \\
\hline 40 & 1953-1972 & $\begin{array}{l}\text { Nitraria sphaerocarpa, } \\
\text { Ephedra przewalskii }\end{array}$ & \\
\hline
\end{tabular}

\subsection{Soil sampling}

In April 2012, a total of 18 sampling plots (6 chronosequence $\times 3$ replications) were selected within a distance of 1.0-1.5 km to avoid pseudoreplication. Five soil sampling sub-plots with each area of 10 $\mathrm{m} \times 10 \mathrm{~m}$ were randomly established at each sampling plot with a minimum separation distance of $100 \mathrm{~m}$. Fifteen soil cores were randomly collected in each sub-plot at depths of 0-20, 20-40 and $40-60 \mathrm{~cm}$ by a sample probe. In each sampling plot, 25 sub-samples from the same depth (i.e. 5 soil cores for each depth in each sub-plot $\times 5$ sub-plots) were mixed to form one composite sample to reduce the effect of natural micro-variability. A total of 54 composite soil samples (i.e. 18 sampling plots $\times 3$ composite soil samples per sampling plot) were used for the analysis. Visible roots, coarse plant debris and stone fragments were removed manually at the time of sampling. In each sub-plot, we collected three additional soil samples to determine bulk density using ring method at depths of 0-20, 20-40 and 40-60 cm. Soil samples were crushed and divided into two portions. One portion was used to analyze aggregate-size distribution, and the other was used to determine the total soil OC and N contents, and other physical-chemical properties.

\subsection{Laboratory analyses}

\subsubsection{Water-stable aggregate (WSA) fraction}

WSA were fractionated according to the wet-sieving method (Six et al., 1998; Puget et al., 2000). 
Briefly, 100 g soil was successively passed by 4 sieves with decreasing mesh diameter (2, 1, 0.25 and $0.053 \mathrm{~mm}$ ) and gently suspended in water for $5 \mathrm{~min}$ at room temperature. Then, aggregates were separated by moving the sieves up and down $(3 \mathrm{~cm}) 50$ times for $2 \mathrm{~min}$. Finally, soil aggregates were separated into five size classes: $>2,1-2,0.25-1,0.053-0.25$ and $<0.053 \mathrm{~mm}$. In this study, we divided the size fractions of WSA into three classes: macroaggregates $(>0.25 \mathrm{~mm})$, microaggregates (0.053-0.25 mm; Miwa et al., 2014), and silt+clay particles $(<0.053 \mathrm{~mm}$; Manna et al., 2007). After a 2-min cycle, WSA remained on sieves were gently poured into pre-weighed aluminum pan, oven dried at $60^{\circ} \mathrm{C}$ for $48 \mathrm{~h}$, weighed, and prepared for mean weight diameter (MWD) calculation. The MWD of each soil sample was calculated by Eq. 1 (Yamashita et al., 2006; Spohn and Giani, 2011).

$$
\mathrm{MWD}=\sum_{i=1}^{n} X_{i} W_{j}
$$

Where, $X_{i}$ is the mean diameter of each size fraction, and $W_{j}$ is the proportion of total sample weight in the corresponding size fraction.

\subsubsection{Sample analysis}

We sieved soils through a 2-mm mesh to analyze $\mathrm{pH}$, electrical conductivity (EC) and soil particle composition, and a $0.25-\mathrm{mm}$ mesh to analyze soil $\mathrm{OC}$ and $\mathrm{N}$ contents. Soil $\mathrm{pH}$ values were determined with a glass electrode using a 1:1 soil:water ratio. Soil EC was measured with an EC meter using a 1:5 soil:water ratio. Soil particle composition was determined by the hydrometer method (Institute of Soil Science, Chinese Academy of Sciences, 1978). Soil OC and N contents of the entire soil profile and in all size fractions of WSA were determined by the $\mathrm{K}_{2} \mathrm{Cr}_{2} \mathrm{O}_{7}-\mathrm{H}_{2} \mathrm{SO}_{4}$ digestion method (Nelson and Sommers, 1996) and Kjeldahl procedure (Bremner, 1996), respectively. Measurement of root biomass is detailed in the study of DuPont et al. (2010). In this study, 6-cm diameter soil cores from each sub-plot were collected at depths of 0-20, 20-40 and 40-60 $\mathrm{cm}$ ( $n=15$ per plot). All root samples were hand-sorted in deionized water, and roots were recovered by filtering cleaned samples through a $0.25-\mathrm{mm}$ mesh. Roots were dried at $50^{\circ} \mathrm{C}$ for $48 \mathrm{~h}$ and weighed for determining the root biomass.

\subsubsection{Statistical analysis}

We conducted Pearson correlation tests to examine the OC and N contents in WSA at different soil depths. We performed stepwise multiple-linear regression analysis to improve the understanding of how WSA fractions, and OC and N contents in different size fractions of WSA affected the MWD, OC and $\mathrm{N}$ in total soils. Two-way ANOVA was used to analyze the effects of abandonment age of agricultural lands, soil depth, and their interactions on soil properties, WSA sizes, MWD, and OC and $\mathrm{N}$ contents in different size fractions of WSA. All analyses were conducted using SPSS 19.0 software for Windows (SPSS Inc., IL, USA). The results were presented as mean \pm SD $(n=3)$. SigmaPlot 10.0 software was also used for graphics.

\section{Results}

\subsection{Basic properties of soils}

The average soil $\mathrm{pH}$ and EC in abandoned agricultural lands at sampling depths were 8.04 and $1.72 \mathrm{~ms} / \mathrm{cm}$, respectively, which were slightly higher than those in cultivated land at the $0-40 \mathrm{~cm}$ depth and lower than those in cultivated land at the 40-60 cm depth (Table 2). Agricultural land abandonment affected the distributions of silt and clay considerably. That is, agricultural abandonment made an increase of silt percentage from $20.01 \%$ in cultivated land to $45.94 \%$ in 40-year abandoned agricultural land, and a decrease of clay percentage from 33.56\% in cultivated land to $12.37 \%$ in 40 -year abandoned agricultural land at the 0-20 cm depth (Table 2). Compared to the conditions in cultivated land, the total OC and N contents increased by $33.6 \%$ and $9.23 \%$ in the 20-40 cm soil layer after 40 years of agricultural land abandonment, respectively; however, the total OC and total $\mathrm{N}$ contents in the $0-20$ and 40-60 cm depths decreased after agricultural land abandonment. Agricultural abandonment resulted in the soil bulk density decreased in the $0-40 \mathrm{~cm}$ 
soil layer but increased in the 40-60 cm soil layer.

The age of agricultural land abandonment and soil depth had significant effects on soil EC, bulk density, total OC and N contents, and particle size distribution (Table 2). The interaction of land abandonment age and soil depth had a significant $(P<0.05)$ effect on soil physical-chemical properties at depths of 0-60 cm (Table 2).

Table 2 Soil physical-chemical properties at different soil depths in agricultural lands with different abandonment ages

\begin{tabular}{|c|c|c|c|c|c|c|c|c|}
\hline \multirow{2}{*}{$\begin{array}{l}\text { ALA } \\
\text { (a) }\end{array}$} & \multirow{2}{*}{$\mathrm{pH}$} & \multirow{2}{*}{$\begin{array}{c}\mathrm{EC} \\
(\mathrm{ms} / \mathrm{cm})\end{array}$} & \multirow{2}{*}{$\begin{array}{c}\mathrm{BD} \\
\left(\mathrm{g} / \mathrm{cm}^{3}\right)\end{array}$} & \multirow{2}{*}{$\begin{array}{c}\text { Total OC } \\
(\mathrm{g} / \mathrm{kg})\end{array}$} & \multirow{2}{*}{$\begin{array}{c}\text { Total N } \\
\text { (g/kg) }\end{array}$} & \multicolumn{3}{|c|}{ Particle size proportion (\%) } \\
\hline & & & & & & Sand & Clay & Silt \\
\hline \multicolumn{9}{|c|}{$0-20 \mathrm{~cm}$ soil layer } \\
\hline 0 & $7.87 \pm 0.11^{\mathrm{a}}$ & $0.91 \pm 0.11^{\mathrm{a}}$ & $1.47 \pm 0.33^{\mathrm{a}}$ & $5.94 \pm 0.12^{\mathrm{a}}$ & $0.68 \pm 0.04^{\mathrm{a}}$ & $46.43 \pm 0.47^{\mathrm{a}}$ & $33.56 \pm 1.12^{\mathrm{a}}$ & $20.01 \pm 1.73^{\mathrm{a}}$ \\
\hline 3 & $7.95 \pm 0.15^{\mathrm{a}}$ & $1.02 \pm 0.21^{\mathrm{a}}$ & $1.46 \pm 0.94^{\mathrm{ab}}$ & $4.89 \pm 0.21^{\mathrm{b}}$ & $0.57 \pm 0.03^{\mathrm{b}}$ & $48.90 \pm 2.64^{\mathrm{ab}}$ & $16.40 \pm 0.73^{\mathrm{b}}$ & $34.70 \pm 2.03^{b}$ \\
\hline 12 & $7.97 \pm 0.23^{\mathrm{a}}$ & $1.97 \pm 0.24^{\mathrm{b}}$ & $1.41 \pm 0.22^{\mathrm{bc}}$ & $4.36 \pm 0.14^{\mathrm{c}}$ & $0.51 \pm 0.01^{\mathrm{c}}$ & $52.25 \pm 3.70^{\mathrm{b}}$ & $14.20 \pm 2.20^{\mathrm{bc}}$ & $33.54 \pm 3.74^{\mathrm{bc}}$ \\
\hline 20 & $8.13 \pm 0.19^{\mathrm{a}}$ & $2.12 \pm 0.31^{\mathrm{bc}}$ & $1.34 \pm 0.42^{\mathrm{cd}}$ & $3.98 \pm 0.11^{\mathrm{cd}}$ & $0.47 \pm 0.03^{\mathrm{cd}}$ & $57.09 \pm 1.14^{\mathrm{c}}$ & $12.74 \pm 1.76^{\mathrm{bc}}$ & $30.17 \pm 1.18^{c}$ \\
\hline 30 & $8.18 \pm 0.32^{\mathrm{a}}$ & $2.79 \pm 0.76^{c}$ & $1.33 \pm 0.14^{\text {cd }}$ & $3.87 \pm 0.15^{\mathrm{d}}$ & $0.45 \pm 0.01^{\mathrm{cd}}$ & $46.19 \pm 1.61^{\mathrm{a}}$ & $13.54 \pm 1.25^{\mathrm{bc}}$ & $40.27 \pm 2.82^{\mathrm{d}}$ \\
\hline 40 & $8.22 \pm 0.13^{\mathrm{a}}$ & $3.12 \pm 0.35^{\mathrm{d}}$ & $1.27 \pm 0.55^{\mathrm{d}}$ & $3.82 \pm 0.15^{\mathrm{d}}$ & $0.44 \pm 0.02^{\mathrm{d}}$ & $41.69 \pm 3.86^{\mathrm{d}}$ & $12.37 \pm 0.91^{\mathrm{c}}$ & $45.94 \pm 2.56^{\mathrm{e}}$ \\
\hline \multicolumn{9}{|c|}{ 20-40 cm soil layer } \\
\hline 0 & $7.81 \pm 0.15^{\mathrm{a}}$ & $0.96 \pm 0.82^{\mathrm{a}}$ & $1.54 \pm 0.25^{\mathrm{a}}$ & $4.05 \pm 0.12^{\mathrm{d}}$ & $0.59 \pm 0.04^{\mathrm{ab}}$ & $33.29 \pm 0.85^{\mathrm{a}}$ & $48.32 \pm 1.03^{\mathrm{a}}$ & $18.39 \pm 2.61^{\mathrm{a}}$ \\
\hline 3 & $8.01 \pm 0.25^{\mathrm{ab}}$ & $1.09 \pm 0.38^{\mathrm{ab}}$ & $1.50 \pm 0.17^{\mathrm{ab}}$ & $4.07 \pm 0.17^{\mathrm{c}}$ & $0.56 \pm 0.02^{\mathrm{b}}$ & $52.56 \pm 2.20^{\mathrm{b}}$ & $27.84 \pm 2.02^{\mathrm{b}}$ & $19.60 \pm 4.10^{\mathrm{a}}$ \\
\hline 12 & $8.09 \pm 0.08^{\mathrm{bc}}$ & $1.18 \pm 0.26^{\mathrm{ab}}$ & $1.49 \pm 0.17^{\mathrm{ab}}$ & $4.12 \pm 0.18^{\mathrm{cd}}$ & $0.54 \pm 0.02^{\mathrm{b}}$ & $62.60 \pm 1.76^{c}$ & $12.53 \pm 2.74^{\mathrm{c}}$ & $24.87 \pm 1.20^{\mathrm{b}}$ \\
\hline 20 & $8.17 \pm 0.21^{\mathrm{bc}}$ & $1.51 \pm 0.51^{\mathrm{ab}}$ & $1.47 \pm 0.35^{\mathrm{ab}}$ & $4.30 \pm 0.15^{\mathrm{cd}}$ & $0.56 \pm 0.01^{\mathrm{ab}}$ & $42.47 \pm 1.64^{\mathrm{d}}$ & $19.38 \pm 2.91^{\mathrm{d}}$ & $38.16 \pm 1.48^{\mathrm{c}}$ \\
\hline 30 & $8.21 \pm 0.15^{c}$ & $1.64 \pm 0.12^{\mathrm{ab}}$ & $1.46 \pm 0.50^{\mathrm{ab}}$ & $4.80 \pm 0.14^{\mathrm{b}}$ & $0.63 \pm 0.01^{\mathrm{a}}$ & $34.27 \pm 3.15^{\mathrm{a}}$ & $17.18 \pm 1.53^{\mathrm{de}}$ & $48.56 \pm 2.42^{\mathrm{d}}$ \\
\hline 40 & $8.23 \pm 0.12^{\mathrm{c}}$ & $1.74 \pm 0.46^{\mathrm{b}}$ & $1.45 \pm 0.35^{\mathrm{b}}$ & $6.10 \pm 0.25^{\mathrm{a}}$ & $0.65 \pm 0.05^{\mathrm{a}}$ & $32.27 \pm 1.16^{\mathrm{a}}$ & $14.38 \pm 1.83^{\mathrm{cd}}$ & $53.36 \pm 1.65^{\mathrm{e}}$ \\
\hline \multicolumn{9}{|c|}{ 40-60 cm soil layer } \\
\hline 0 & $8.04 \pm 0.12^{\mathrm{a}}$ & $2.05 \pm 0.32^{\mathrm{a}}$ & $1.52 \pm 0.12^{\mathrm{a}}$ & $4.98 \pm 0.10^{\mathrm{a}}$ & $0.67 \pm 0.05^{\mathrm{a}}$ & $37.91 \pm 1.22^{\mathrm{ab}}$ & $40.79 \pm 4.19^{\mathrm{a}}$ & $21.30 \pm 5.22^{\mathrm{a}}$ \\
\hline 3 & $7.98 \pm 0.12^{\mathrm{a}}$ & $1.93 \pm 0.38^{\mathrm{a}}$ & $1.53 \pm 0.21^{\mathrm{a}}$ & $4.98 \pm 0.08^{\mathrm{a}}$ & $0.59 \pm 0.03^{\mathrm{b}}$ & $37.58 \pm 1.63^{\mathrm{ab}}$ & $38.84 \pm 2.07^{\mathrm{a}}$ & $23.58 \pm 2.81^{\mathrm{ab}}$ \\
\hline 12 & $7.92 \pm 0.11^{\mathrm{a}}$ & $1.74 \pm 0.15^{\mathrm{ab}}$ & $1.53 \pm 0.33^{\mathrm{a}}$ & $4.90 \pm 0.09^{\mathrm{a}}$ & $0.57 \pm 0.01^{\mathrm{b}}$ & $33.85 \pm 3.78^{\mathrm{bc}}$ & $38.31 \pm 2.77^{\mathrm{a}}$ & $27.84 \pm 4.03^{\mathrm{bc}}$ \\
\hline 20 & $7.90 \pm 0.28^{\mathrm{a}}$ & $1.48 \pm 0.75^{\mathrm{bc}}$ & $1.54 \pm 0.42^{\mathrm{a}}$ & $4.71 \pm 0.08^{\mathrm{ab}}$ & $0.55 \pm 0.04^{\mathrm{b}}$ & $31.91 \pm 0.54^{\mathrm{c}}$ & $36.82 \pm 1.74^{\mathrm{a}}$ & $31.27 \pm 1.67^{\text {cd }}$ \\
\hline 30 & $7.86 \pm 0.15^{\mathrm{a}}$ & $1.29 \pm 0.74^{\mathrm{c}}$ & $1.56 \pm 0.17^{\mathrm{a}}$ & $3.77 \pm 0.12^{\mathrm{c}}$ & $0.48 \pm 0.06^{\mathrm{c}}$ & $34.89 \pm 4.26^{\mathrm{bc}}$ & $31.87 \pm 3.53^{\mathrm{b}}$ & $33.24 \pm 1.75^{\mathrm{bcd}}$ \\
\hline 40 & $7.78 \pm 0.15^{\mathrm{a}}$ & $1.15 \pm 0.69^{c}$ & $1.56 \pm 0.26^{\mathrm{a}}$ & $4.01 \pm 0.11^{\mathrm{bc}}$ & $0.49 \pm 0.03^{c}$ & $42.70 \pm 2.87^{\mathrm{a}}$ & $20.48 \pm 6.28^{c}$ & $36.82 \pm 8.81^{\mathrm{d}}$ \\
\hline \multicolumn{9}{|c|}{ Least significant difference (LSD) } \\
\hline $\begin{array}{l}\text { ALA } \\
\text { (A) }\end{array}$ & 1.70 & $2.12^{* *}$ & $33.45^{* * *}$ & $7.47^{* *}$ & $5.18^{* *}$ & $91.65^{* * *}$ & $47.48^{* * *}$ & $85.36^{* * *}$ \\
\hline $\begin{array}{l}\text { Soil } \\
\text { depth } \\
\text { (B) }\end{array}$ & $19.62^{* * *}$ & $3.84^{*}$ & $10.04^{* * *}$ & $19.76^{* * *}$ & $51.33^{* * *}$ & $184.20^{* * *}$ & $343.26^{* * *}$ & $24.91^{* * *}$ \\
\hline $\mathrm{A} \times \mathrm{B}$ & $4.56^{*}$ & $18.31^{* *}$ & $4.66^{* * *}$ & $32.98^{* * *}$ & $12.71^{* * * *}$ & $30.65^{* * *}$ & $13.36^{* * *}$ & $21.51^{* * *}$ \\
\hline
\end{tabular}

Note: ALA, age of land abandonment; EC, electrical conductivity; BD, bulk density; OC, organic carbon; N, nitrogen. Lowercase letters indicate significance at $P<0.05$ level between different ages of agricultural land abandonment. Mean $\pm \mathrm{SD}, n=3 .{ }^{*},{ }^{* *}$ and ${ }^{* * *}$ indicate significance at $P<0.05, P<0.01$ and $P<0.001$ levels, respectively.

\subsection{WSA sizes and stability}

In cultivated land, the average MWD of WSA at soil depths of 0-20, 20-40 and 40-60 cm was $0.106 \pm 0.01,0.152 \pm 0.03$ and $0.150 \pm 0.06 \mathrm{~mm}$, respectively. It increased to $0.435 \pm 0.09,0.596 \pm 0.02$ and $0.487 \pm 0.02 \mathrm{~mm}$ at soil depths of $0-20,20-40$ and $40-60 \mathrm{~cm}$ after 40 years of agricultural abandonment (Fig. 1). Agricultural land abandonment and the interaction of land abandonment age and soil depth had significant effect on MWD at depths of 0-60 $\mathrm{cm}(P<0.001$; Table 3).

Soil depth had no impact on the proportion of WSA $>2 \mathrm{~mm}$; however, the age of agricultural land abandonment and interactive effect of land abandonment age and soil depth significantly affected the proportions of all WSA fractions $(P<0.001$; Table 3$)$. The increment of MWD of aggregates in abandoned agricultural lands is caused by an increase in the proportion of aggregates with sizes $0.25-2 \mathrm{~mm}$. The proportion of WSA sizes $<0.053 \mathrm{~mm}$ decreased with increasing abandonment age at soil depths of $0-20,20-40$ and 40-60 cm (Fig. 1). The proportion of WSA sizes $>2 \mathrm{~mm}$ remained less than $9 \%$ in all analyzed samples. 

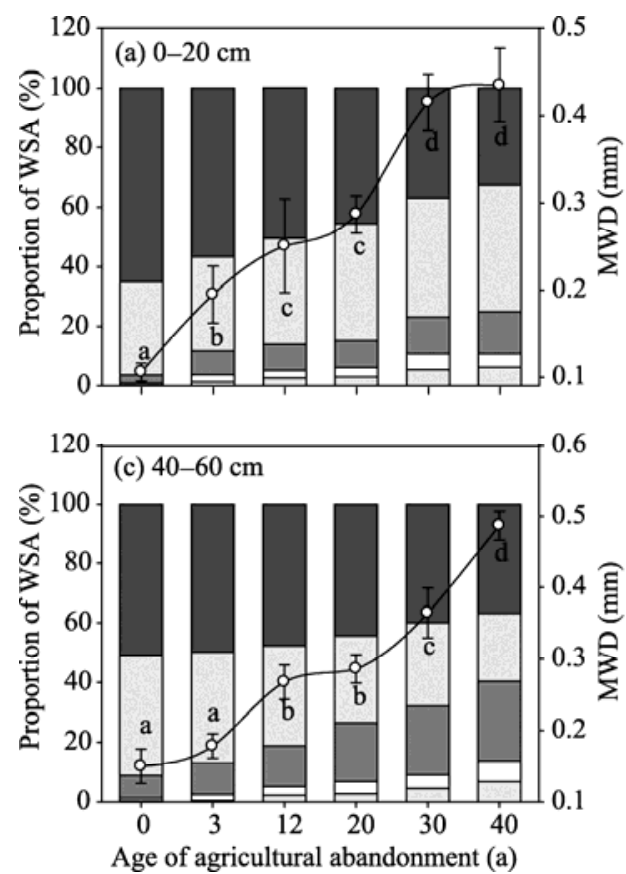

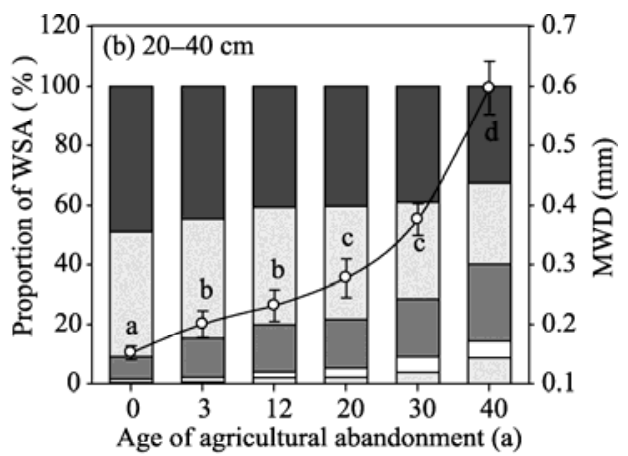

Size fraction of WSA (mm) $\multimap-$ MWD

ए $>2$

ए $1-2$

ऍ0.25-1

ए $0.053-0.25$

$\longrightarrow 0.053$

Fig. 1 WSA (water-stable aggregates) proportion and MWD (mean weight diameter) at different soil depths in agricultural lands with different abandonment ages. Values were calculated from three independent samples per sub-plot. Error bars depict standard deviations. Different lowercase letters indicate significance at $P<0.05$ level between different land abandonment ages.

Table 3 Two-way ANOVA for effects of agricultural abandonment age and soil depth on the proportion of WSA and MWD

\begin{tabular}{|c|c|c|c|c|c|c|}
\hline \multirow{3}{*}{ Variable } & \multicolumn{5}{|c|}{ Proportion of WSA } & \multirow{3}{*}{ MWD } \\
\hline & \multicolumn{3}{|c|}{ Macroaggregates } & \multirow{2}{*}{$\begin{array}{l}\text { Microaggregates } \\
(0.053-0.25 \mathrm{~mm})\end{array}$} & \multirow{2}{*}{$\begin{array}{l}\text { Silt+clay particles } \\
\quad(<0.053 \mathrm{~mm})\end{array}$} & \\
\hline & $>2 \mathrm{~mm}$ & $1-2 \mathrm{~mm}$ & $0.25-1 \mathrm{~mm}$ & & & \\
\hline Abandonment age (A) & $210.99^{* * *}$ & $203.19^{* * * *}$ & $58.69^{* * * *}$ & $14.23^{* * * *}$ & $18.01^{* * *}$ & $219.51^{* * *}$ \\
\hline Soil depth (B) & 2.36 & $13.35^{* * *}$ & $82.69^{* * * *}$ & $27.71^{* * *}$ & $28.10^{* * *}$ & 3.18 \\
\hline $\mathrm{A} \times \mathrm{B}$ & $7.61^{* * *}$ & $10.98^{* * *}$ & $4.34^{* *}$ & $9.16^{* * *}$ & $4.38^{* *}$ & $8.72^{* * *}$ \\
\hline
\end{tabular}

Note: WSA, water-stable aggregates; MWD, mean weight diameter. The F-ratio is indicated for abandoned agricultural lands (excluding cultivated land). ${ }^{* *}$ and ${ }^{* * *}$ indicate significance at $P<0.01$ and $P<0.001$ levels, respectively. $\mathrm{A} \times \mathrm{B}$ : interactive effect of land abandonment age and soil depth.

\subsection{Soil OC and $\mathbf{N}$ contents in WSA}

Generally, the soil OC and N contents increased with decreasing sizes of WSA, and a majority of soil OC and $\mathrm{N}$ were concentrated in WSA sizes $<0.053 \mathrm{~mm}$ across all depths over long-term agricultural land abandonment (Fig. 2). Soil OC content in WSA sizes $<0.053 \mathrm{~mm}$ across the three depths ranged from 2.03 to $3.26 \mathrm{~g} / \mathrm{kg}$, accounting for $51.41 \%$ to $55.59 \%$ of the total soil OC content. Soil N content in WSA sizes $<0.053 \mathrm{~mm}$ ranged from 0.21 to $0.33 \mathrm{~g} / \mathrm{kg}$, occupying $42.61 \%$ to $48.94 \%$ of the total soil $\mathrm{N}$ content.

At the depth of $0-60 \mathrm{~cm}$, soil OC and $\mathrm{N}$ contents in WSA sizes $>2 \mathrm{~mm}$ increased with increasing age of agricultural abandonment. A significant positive linear relationship $(P<0.01)$ was observed between soil OC content in WSA sizes $>2 \mathrm{~mm}$ and age of agricultural land abandonment. However, a significant negative relationship $(P<0.01)$ was observed between soil OC content in WSA sizes $<0.053 \mathrm{~mm}$ and land abandonment age. Agricultural abandonment increased soil OC and N contents in WSA sizes $0.25-2 \mathrm{~mm}$ at the $20-60 \mathrm{~cm}$ soil depth but decreased their contents at the depth of 0-20 cm (Fig. 2). The changes of soil OC and N contents in agricultural lands with different land abandonment ages were approximated with a linear function. Age of agricultural land abandonment, soil depth, and interactive effect of agricultural abandonment age and soil depth significantly affected the distributions of soil OC and N contents almost in all size fractions of WSA (Table 4). 


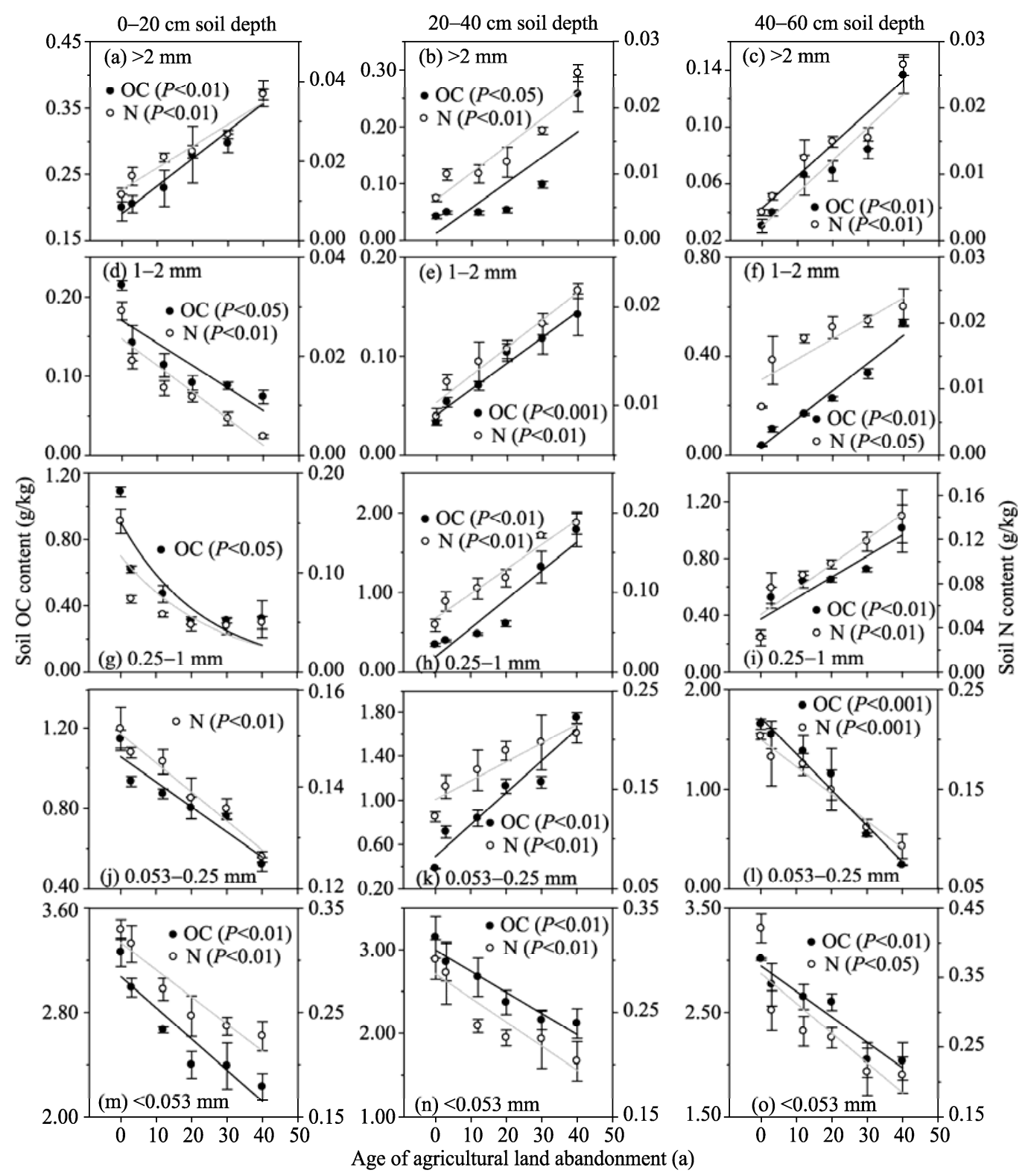

Fig. 2 Soil organic carbon (OC; the left vertical axis in each graph) and nitrogen ( $\mathrm{N}$; the right vertical axis in each graph) contents in different sizes of WSA at different soil depths in agricultural lands with different abandonment ages. Values were calculated from three independent samples per sampling plot. Error bars depict standard deviations. The black line indicates the relationship between soil OC content in WSA and age of agricultural land abandonment, and the gray line indicates the relationship between soil N content in WSA and age of agricultural land abandonment.

\subsection{Relationship of MWD with soil OC and N contents}

As shown in Table 5, at depths of $0-20$ and $20-40 \mathrm{~cm}$, total soil OC and $\mathrm{N}$ contents were significantly correlated with soil OC and N contents in WSA sizes $0.053-0.25 \mathrm{~mm}$, respectively. At the depth of 40-60 cm, total soil OC content was significantly correlated with soil OC content in WSA sizes $<0.053 \mathrm{~mm}$, and total soil $\mathrm{N}$ content was significantly correlated with $\mathrm{N}$ content in WSA sizes $0.053-0.25 \mathrm{~mm}$. At depths of $0-20$ and 20-40 cm, MWD was positively correlated with soil OC and $\mathrm{N}$ contents in WSA sizes $>2 \mathrm{~mm}(P<0.001)$. At the depth of 40-60 cm, MWD was negatively correlated with soil OC content in WSA sizes $<0.053 \mathrm{~mm}(P<0.001)$ and positively correlated with soil $\mathrm{N}$ content in WSA sizes $>2 \mathrm{~mm}(P<0.001)$. 
Table 4 Two-way ANOVA for effects of land abandonment age and soil depth on soil OC and N contents in different sizes of WSA

\begin{tabular}{|c|c|c|c|c|c|}
\hline \multirow{2}{*}{ Variable } & \multicolumn{5}{|c|}{ Soil OC content in different sizes of WSA } \\
\hline & $>2 \mathrm{~mm}$ & $1-2 \mathrm{~mm}$ & $0.25-1 \mathrm{~mm}$ & $0.053-0.25 \mathrm{~mm}$ & $<0.053 \mathrm{~mm}$ \\
\hline Age of agricultural abandonment (A) & $76.12^{* * *}$ & $8.86^{* * *}$ & $52.99^{* * *}$ & $9.83^{* * *}$ & $10.48^{* * *}$ \\
\hline Soil depth (B) & $461.81^{* * *}$ & $29.99^{* * *}$ & $54.01^{* * *}$ & $30.23^{* * *}$ & 0.81 \\
\hline $\mathrm{A} \times \mathrm{B}$ & $5.79^{* * *}$ & $10.95^{* * *}$ & $72.01^{* * *}$ & $103.09^{* * *}$ & 0.49 \\
\hline \multirow{2}{*}{ Variable } & \multicolumn{5}{|c|}{ Soil N content in different sizes of WSA } \\
\hline & $>2 \mathrm{~mm}$ & $1-2 \mathrm{~mm}$ & $0.25-1 \mathrm{~mm}$ & $0.053-0.25 \mathrm{~mm}$ & $<0.053 \mathrm{~mm}$ \\
\hline Age of agricultural abandonment (A) & $286.23^{* * *}$ & 0.441 & $35.41^{* * *}$ & 2.03 & $4.62^{* *}$ \\
\hline Soil depth (B) & $264.24^{* * *}$ & $16.93^{* * *}$ & $120.65^{* * *}$ & $15.40^{* * *}$ & 2.04 \\
\hline $\mathrm{A} \times \mathrm{B}$ & $4.35^{* *}$ & $93.49^{* * *}$ & $68.43^{* * *}$ & $13.14^{* * *}$ & 0.33 \\
\hline
\end{tabular}

Note: The $F$-ratio is indicated for abandoned agricultural lands (excluding cultivated land). ${ }^{* *}$ and ${ }^{* * *}$ indicate significance at $P<0.01$ and $P<0.001$ levels, respectively. $n=15$. A $\times$ B: interactive effect of land abandonment age and soil depth.

Table 5 Stepwise regression analyses between soil OC content in WSA sizes and total soil OC content, soil N content in WSA sizes and total soil N content, MWD and WSA, MWD and soil OC and N contents in WSA sizes at different soil depths in abandoned agricultural lands (excluding cultivated land)

\begin{tabular}{|c|c|c|}
\hline Dependent variable & Regression equation & $R^{2}$ \\
\hline \multicolumn{3}{|l|}{ 0-20 cm soil layer } \\
\hline Total OC content & Total OC content $=2.88+2.58\left(\mathrm{OC}_{0.053-0.25 \mathrm{~mm}}\right)$ & $0.862^{* * *}$ \\
\hline \multirow[t]{2}{*}{ Total N content } & Total $\mathrm{N}$ content $=0.403+10.65\left(\mathrm{~N}_{0.053-0.25} \mathrm{~mm}\right)$ & $0.671^{* * *}$ \\
\hline & MWD $=0.129+0.051(W S A>2 \mathrm{~mm})$ & $0.975^{* * *}$ \\
\hline \multirow[t]{2}{*}{ MWD } & $\mathrm{MWD}=1.25\left(\mathrm{OC}_{>2 \mathrm{~mm}}\right)-0.03$ & $0.634^{* * *}$ \\
\hline & $M W D=13.187\left(\mathrm{~N}_{>2 \mathrm{~mm}}\right)-0.062$ & $0.875^{* * *}$ \\
\hline \multicolumn{3}{|l|}{ 20-40 cm soil layer } \\
\hline Total OC content & Total OC content $=3.77+9.17\left(\mathrm{OC}_{0.053-0.25 \mathrm{~mm}}\right)$ & $0.924^{* * *}$ \\
\hline \multirow[t]{2}{*}{ Total N content } & Total $\mathrm{N}$ content $=0.446+0.934\left(\mathrm{~N}_{0.053-0.25 \mathrm{~mm}}\right)$ & $0.658^{* * *}$ \\
\hline & $\mathrm{MWD}=0.049\left(\mathrm{WSA}_{>2 \mathrm{~mm}}\right)+0.165$ & $0.967^{* * *}$ \\
\hline \multirow[t]{2}{*}{ MWD } & $\mathrm{MWD}=0.38\left(\mathrm{OC}_{>2 \mathrm{~mm}}\right)-0.09$ & $0.927^{* * *}$ \\
\hline & $\mathrm{MWD}=24.48\left(\mathrm{~N}_{>2 \mathrm{~mm}}\right)-0.01$ & $0.889^{* * * *}$ \\
\hline \multicolumn{3}{|l|}{ 40-60 cm soil layer } \\
\hline Total OC content & Total OC content $=0.90+3.59\left(\mathrm{OC}_{<0.053 \mathrm{~mm}}\right)$ & $0.781^{* * *}$ \\
\hline \multirow[t]{2}{*}{ Total N content } & Total $\mathrm{N}$ content $=0.7131 .43\left(\mathrm{~N}_{0.053-0.25 \mathrm{~mm}}\right)$ & $0.807^{* * *}$ \\
\hline & $\mathrm{MWD}=0.028+0.057\left(\mathrm{WSA}_{1-2 \mathrm{~mm}}\right)$ & $0.853^{* * *}$ \\
\hline \multirow[t]{2}{*}{ MWD } & $\mathrm{MWD}=0.505-0.20\left(\mathrm{OC}_{<0.053 \mathrm{~mm}}\right)$ & $0.878^{* * *}$ \\
\hline & $\mathrm{MWD}=0.087+15.07\left(\mathrm{~N}_{>2 \mathrm{~mm}}\right)$ & $0.920^{* * *}$ \\
\hline
\end{tabular}

Note: $\mathrm{OC}_{>2 \mathrm{~mm}}, \mathrm{OC}_{0.053-0.25 \mathrm{~mm}}$ and $\mathrm{OC}_{<0.053 \mathrm{~mm}}$ refer to soil organic carbon in WSA sizes $>2,0.053-0.25$ and $<0.053 \mathrm{~mm}$, respectively. $\mathrm{N}_{>2 \mathrm{~mm}}$ and $\mathrm{N}_{0.053-0.25 \mathrm{~mm}}$ refer to soil nitrogen content in WSA sizes $>2$ and 0.053-0.25 mm, respectively. WSA $>2 \mathrm{~mm}$ and $\mathrm{WSA}_{1-2 \mathrm{~mm}}$ refer to the proportions of WSA with size fractions of $>2$ and $1-2 \mathrm{~mm}$, respectively. ${ }^{* * *}$ means significance at $P<0.001$ level.

\subsection{Relationship of soil properties with soil $\mathrm{OC}$ and $\mathrm{N}$ contents}

Soil OC and $\mathrm{N}$ contents in WSA sizes $<0.053 \mathrm{~mm}$ were linearly positively correlated with silt+clay content $(P<0.001$; Fig. 3); however, soil OC and $\mathrm{N}$ contents in WSA sizes $>2 \mathrm{~mm}$ were negatively correlated with silt+clay content. Soil EC was significantly negatively correlated with soil OC and $\mathrm{N}$ contents in WSA sizes $0.053-2 \mathrm{~mm}(P<0.01)$, and the relationship was linear. Soil bulk density had significant negative correlation with soil OC and $N$ contents in WSA sizes $>2$ 
$\mathrm{mm}(P<0.001)$, and positive correlation with soil OC and $\mathrm{N}$ contents in WSA sizes $<0.053 \mathrm{~mm}$ $(P<0.01$ for OC and $P<0.05$ for $\mathrm{N})$. The root biomass was positively exponentially correlated with soil OC and $N$ contents in WSA sizes $0.25-2 \mathrm{~mm}(P<0.001)$, and negatively correlated with soil OC and $\mathrm{N}$ contents in WSA sizes $<0.053 \mathrm{~mm}$ with a linear function $(P<0.01$ for $\mathrm{OC}$ and $P<0.05$ for $\mathrm{N}$ ).

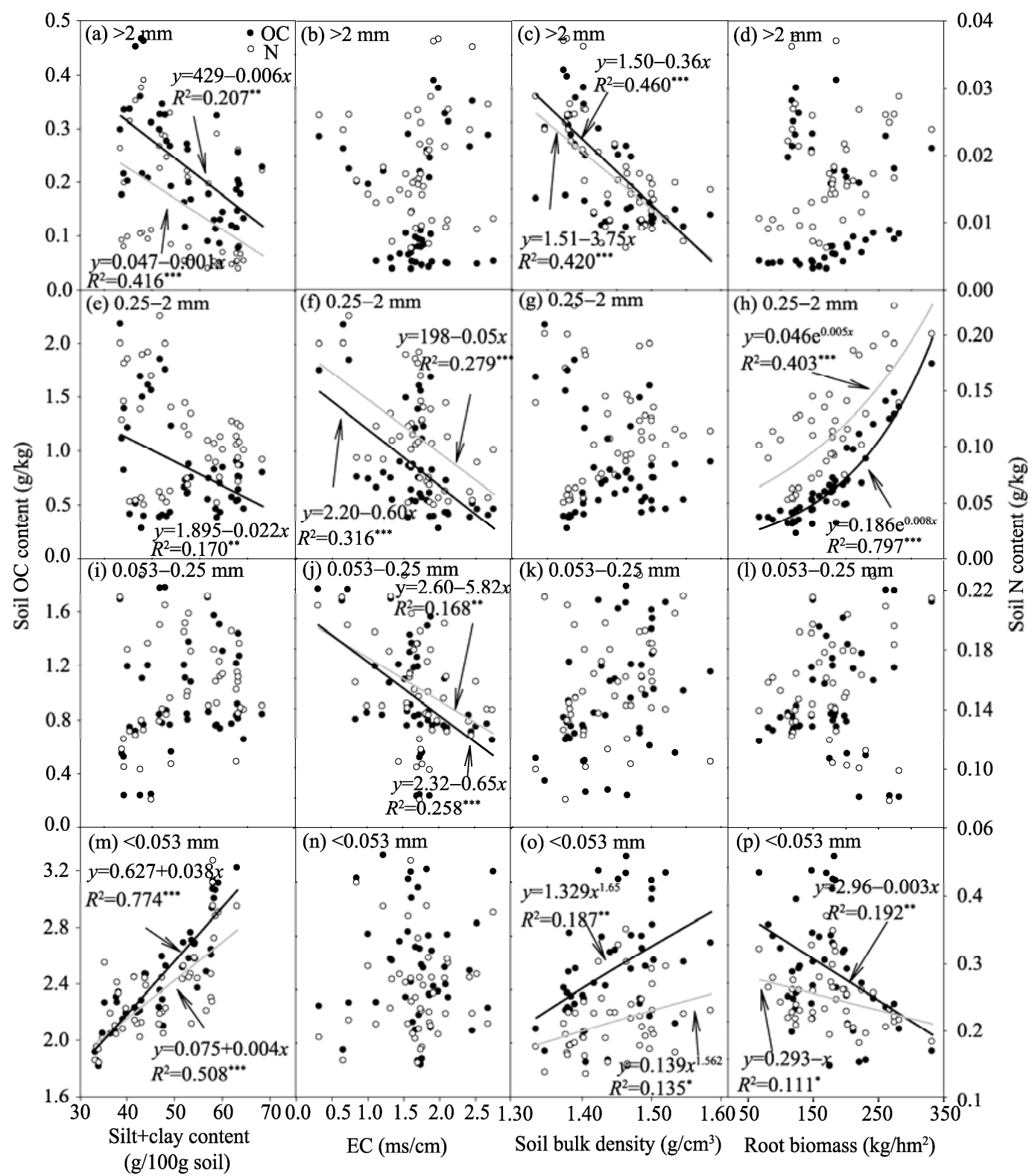

Fig. 3 Correlations of soil properties with soil OC and $\mathrm{N}$ contents in different size fractions of WSA in abandoned agricultural lands (excluding cultivated land). EC, electric conductivity. ${ }^{*},{ }^{* *}$ and ${ }^{* * *}$ indicate significance at $P<0.05, P<0.01$ and $P<0.001$ levels, respectively. The black line indicates the correlation of soil OC content and soil properties, and the gray line indicates the correlation of soil $\mathrm{N}$ content and soil properties.

\subsection{Relationship of soil properties with MWD and C:N ratio of total soil}

The MWD was significantly negatively correlated with soil silt+clay content, EC and bulk density, and exponentially positively correlated with root biomass $(P<0.001$; Fig. 4$)$. The C:N ratio of total soil declined with increasing soil EC values. Moreover, there was no significant correlations of $\mathrm{C}: \mathrm{N}$ ratio of total soil with silt+clay content, bulk density and root biomass. 


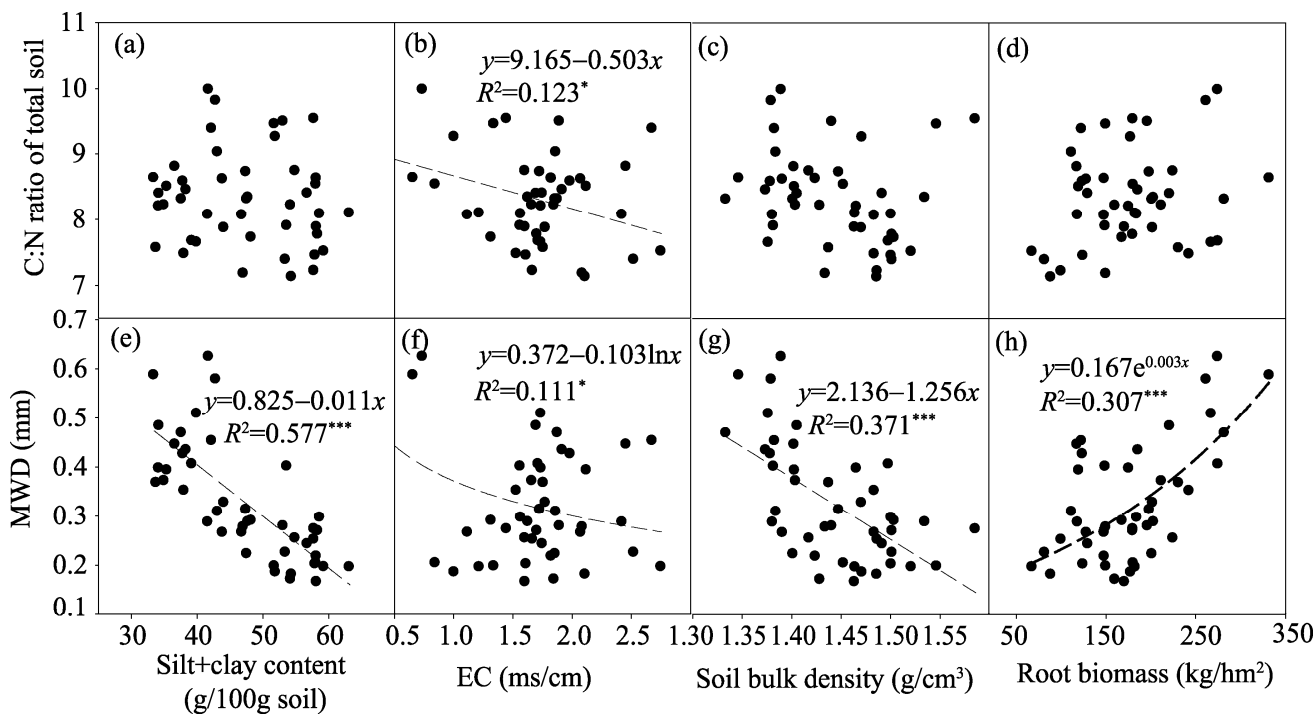

Fig. 4 Correlations of soil properties with MWD and C:N ratio of total soil in abandoned agricultural lands (excluding cultivated land). ${ }^{*}$ and ${ }^{* * *}$ indicate significance at $P<0.05$ and $P<0.001$ levels, respectively.

\section{Discussion}

\subsection{WSA sizes and stability}

The results of this study showed that MWD increased with increasing age of agricultural land abandonment because of a significant restoration of the proportion of WSA sizes $>0.25 \mathrm{~mm}$ and a decrease of the proportion of WSA sizes $<0.053 \mathrm{~mm}$. The increment of soil WSA stability was caused by the bonding of microaggregates and silt+clay particles, which resulted in an increase in the proportion of macroaggregates in abandoned agricultural lands. This study further demonstrated that WSA stability increased with increasing organic matter content enriched in macroaggregates $(P<0.001$; Table 5$)$.

Large soil aggregates have high stability and persistence because they are strongly cemented by organic matter (Six et al., 2000b), which means that ploughing (compared with agricultural abandonment) has a stronger impact on the stability of WSA with larger sizes (Chrenková et al., 2014). This finding demonstrated that the proportion of soil aggregates with sizes $>2 \mathrm{~mm}$ appeared to be a suitable indicator for evaluating the effect of land use change on soil aggregation (Huang et al., 2010). Cultivation can physically disrupt the formation of WSA with larger sizes and therefore soils become more susceptible to degradation and erosion (Ayoubi et al., 2012), especially in semi-arid areas. Soils with larger MWD are more likely to have greater resistance to soil degradation and erosion (Celik, 2005). Accordingly, the abandonment of cultivation has the potential to prevent the soils from wind erosion.

In this study, the MWD exhibited a linear negative correlation with silt+clay content and bulk density $(P<0.001)$, a logarithmic negative correlation with EC $(P<0.05)$, and an exponential positive correlation with root biomass $(P<0.001)$. Therefore, we concluded that the silt+clay content, EC and bulk density have a limited intrinsic capacity for soil aggregation, while the root biomass contributes to soil aggregation in abandoned agricultural lands (Fig. 4).

\subsection{Soil OC and $\mathbf{N}$ contents in abandoned agricultural lands}

As in the cases of many studies in the other regions (e.g. Knops and Tilman, 2000), we had no data on vertical distributions of soil OC and $\mathrm{N}$ contents within particle size fraction before agricultural land abandonment. In addition, the temporal patterns of soil OC and $\mathrm{N}$ dynamics after agricultural abandonment in the study area was not well-documented. Thus, we compared the abandoned agricultural lands to the adjacent long-term agricultural lands, and assumed that the abandoned 
agricultural lands had the similar conditions on the basis of planting and farming practices before abandonment with the cultivated lands.

The variation of soil organic matter in abandoned agricultural lands of semi-arid area was debated over the years because of differences in soil background, aboveground and belowground biomass, as well as management practices. Novara et al. (2014) reported that the organic matter content increased by $13 \%$ after 15 years of vineyard abandonment in a semi-arid environment. A similar increase of OC stocks in soils after cropland abandonment was reported recently for large areas of abandoned lands (Kurganova et al., 2014; Shang et al., 2014). However, these results should be interpreted with caution. According to our data, abandoned agricultural lands contained a lesser amount of OC and N contents than the cultivated land at depths of 0-20 and 40-60 cm (Table 2). Presumably, the lack of rainfall in the study area causes low vegetation productivity and reduces the return of root biomass, resulting in low replacement rate of organic matter pool. This finding is inconsistent with the results of a study in the same climatic region (Li et al., 2006), yet the reasons for the difference are still not understood. The increase of total OC and N contents at the depth of 20-40 cm with increasing land abandonment age indicated that soil organic matter content exhibited vertical difference in abandoned lands. This information is essential to predict total soil OC and $\mathrm{N}$ contents, as well as the vegetation regeneration potential.

In abandoned agricultural lands, soil OC and N contents in silt+clay particles decreased linearly with increasing land abandonment age $(P<0.01)$. The silt+clay content was significantly correlated with organic matter $(P<0.001)$. This may be due to the greater contents of silt+clay particles and the stronger bond between microaggregates and silt+clay particles (Huang et al., 2010). In addition, the silt+clay particles can protect soil OC and $\mathrm{N}$ from microorganises decomposition (Li et al., 2006; Grüeneberg et al., 2013). An important consideration in this study was that the silt+clay particles are susceptible to soil erosion by wind, resulting in the loss of soil organic matter. In our study, agricultural land abandonment resulted in soil OC and N shifting from silt+clay particles to macroaggregates. The larger size particles were found to be more stable than the smaller ones in deeper soil layers because the cementing agent involved in macroaggregates was dominantly inorganic in nature (Barral et al., 1998). The C:N ratio at the 0-20 cm depth decreased with increasing age of agricultural abandonment, which indicated that abandoned agricultural lands own the recalcitrant organic matter pools than agricultural land in the study area (Knops and Tilman, 2000).

According to our findings, soil $\mathrm{OC}$ and $\mathrm{N}$ contents in microaggregates and silt+clay particles were the dominant factors influencing the variations of total OC and $\mathrm{N}$ contents in abandoned agricultural lands (Table 5). Our results confirmed that microaggregates rather than macroaggregates protect the soil organic matter in the long-term (Six and Paustian, 2014). Soil EC was negatively correlated with soil OC and $\mathrm{N}$ contents in microaggregates $(P<0.01)$, implying that $\mathrm{OC}$ and $\mathrm{N}$ in microaggregates were more sensitive to the influence of salinization.

\subsection{Relationship of WSA stability with soil OC and N contents}

Stepwise regression analysis revealed that the differences of aggregate stability caused by agricultural land abandonment mainly resulted from the differences in the contents of OC and $\mathrm{N}$ in macroaggregates with sizes $>2 \mathrm{~mm}$ (Table 5). Root biomass was significantly positively correlated with soil $\mathrm{OC}$ and $\mathrm{N}$ contents in macroaggregates with sizes $0.25-2 \mathrm{~mm}(P<0.001$; Fig. 3$)$. Therefore, roots seemed highly important for the formation of macroaggregates (Fig. 4). This finding is in accordance with the hierarchical model by Tisdall and Oades (1982) and the recent research by Linsler et al. (2013).

In this study, the soil OC and $\mathrm{N}$ contents increased with increasing size of WSA, which indicated the important effect of agricultural abandonment on organic matter dynamics and aggregate stability (Six et al., 2000a; Zhu et al., 2010). These results are in agreement with the concept of aggregate hierarchy that microaggregates are bound together into macroaggregates by transient binding agents (Six et al., 2000b; Ayoubi et al., 2012). Thus, OC and N likely play a major role in improving soil WSA stability. Furthermore, the amount of macroaggregates and subsequent aggregate stability were greater in abandoned agricultural lands than in cultivated lands. 
This fact demonstrated that the recovery of macroaggregates may protect the organic matter against microbial mineralization and losses, and facilitate the OC and $\mathrm{N}$ accumulation in soils. In turn, the physically protected soil organic matter may foster the formation of WSA to improve the soil structure (Ahn et al., 2009; Raiesi, 2012). In general, the different distributions of soil OC and $\mathrm{N}$ contents across different sizes of WSA as a result of agricultural land abandonment reflected the differences in formation mechanisms and water stability of aggregates in arid region of the Minqin Oasis.

\section{Conclusions}

Our findings demonstrated that abandoned agricultural lands tend to change the soil particle composition, resulting in higher WSA stability. Total soil OC and $\mathrm{N}$ contents presented the phenomenon of stratification across soil depths. Agricultural land abandonment contributed to the accumulation of soil OC and $\mathrm{N}$ in macroaggregates with sizes $>0.25 \mathrm{~mm}$. Soil OC and $\mathrm{N}$ contents in macroaggregates with sizes $>2 \mathrm{~mm}$ were the key factors that affected the MWD in abandoned agricultural lands. Moreover, the majority of soil OC and $\mathrm{N}$ still contained in microaggregates $(0.053-0.25 \mathrm{~mm})$ and silt+clay particles $(<0.053 \mathrm{~mm})$, which are the dominating factors influencing the variations of total $\mathrm{OC}$ and $\mathrm{N}$ contents in abandoned agricultural lands. The mentioned OC and $\mathrm{N}$ in WSA sizes $<0.25 \mathrm{~mm}$ were relatively more sensitive to the influences of salinization dynamics, silt+clay content, bulk density and root biomass after agricultural abandonment. The potential for soil $\mathrm{OC}$ and $\mathrm{N}$ sequestration in silt+clay particles suggested that smaller particle sizes play a key role in the formation and stabilization of organic matter in abandoned agricultural lands in arid ecosystems.

\section{Acknowledgements}

This study was funded by the Science \& Technology Pillar Program of Gansu Province (1104FKCH162, 1204FKCH164, 1304FKCH102) and the National Natural Science Foundation of China (31560170). Sincere thanks are extended to Professor SU Yongzhong from the Cold and Arid Regions Environmental and Engineering Research Institute, Chinese Academy of Sciences and Alison BEAMISH at the University of British Columbia for their assistance in English grammar editing. We would like to thank ZHOU Yanfang, LIU Qiang, CHENG Tiaojun and WANG Xiao for their help in soil sampling, lab analysis and data analysis. We also thank Professor GAN Yantai and WANG Shengrong for their constructive and helpful comments provided on an earlier version of this paper.

\section{References}

Ahn M Y, Zimmerman A R, Comerford N B, et al. 2009. Carbon mineralization and labile organic carbon pools in the sandy soils of a north Florida Watershed. Ecosystems, 12(4): 672-685.

Ashagrie Y, Zech W, Guggenberger G, et al. 2007. Soil aggregation, and total and particulate organic matter following conversion of native forests to continuous cultivation in Ethiopia. Soil and Tillage Research, 94(1): 101-108.

Ayoubi S, Karchegani P M, Mosaddeghi M R, et al. 2012. Soil aggregation and organic carbon as affected by topography and land use change in western Iran. Soil and Tillage Research, 121: 18-26.

Barral M T, Arias M, Guérif J. 1998. Effects of iron and organic matter on the porosity and structural stability of soil aggregates. Soil and Tillage Research, 46(3-4): 261-272.

Bonifacio E, Santoni S, Falsone G, et al. 2006. Wet aggregate stability of some Botswana soil profiles. Arid Land Research and Management, 20(1): 15-28.

Bremner J M. 1996. Nitrogen-total. In: Sparks D L. Methods of Soil Analysis. Part 3. Chemical Methods. Madison, WI: Soil Science Society of America, 1085-1121.

Carter M R. 1996. Characterization of soil physical properties and organic matter under long-term primary tillage in a humid climate. Soil and Tillage Research, 38(3-4): 251-263.

Celik I. 2005. Land-use effects on organic matter and physical properties of soil in a southern Mediterranean highland of Turkey. Soil and Tillage Research, 83(2): 270-277.

Chrenková K, Mataix-Solera J, Dlapa P, et al. 2014. Long-term changes in soil aggregation comparing forest and agricultural 
land use in different Mediterranean soil types. Geoderma, 235-236: 290-299.

Cramer V A, Hobbs R J, Standish R J. 2008. What's new about old fields? Land abandonment and ecosystem assembly. Trends in Ecology and Evolution, 23(2): 104-112.

Deng L, Shangguan Z P, Sweeney S. 2013. Changes in soil carbon and nitrogen following land abandonment of farmland on the Loess Plateau, China. PLoS ONE, 8(8): e71923, doi: 10.1371/journal.pone.0071923.

DuPont S T, Culman S W, Ferris H, et al. 2010. No-tillage conversion of harvested perennial grassland to annual cropland reduces root biomass, decreases active carbon stocks, and impacts soil biota. Agriculture, Ecosystems and Environment, 137(1-2): 25-32.

Gabarrón-Galeote M A, Trigalet S, van Wesemael B. 2015. Soil organic carbon evolution after land abandonment along a precipitation gradient in southern Spain. Agriculture, Ecosystems and Environment, 199: 114-123.

Grüeneberg E, Schöening I, Hessenmöller D, et al. 2013. Organic layer and clay content control soil organic carbon stocks in density fractions of differently managed German beech forests. Forest Ecology and Management, 303: 1-10.

Haynes R J. 2000. Labile organic matter as an indicator of organic matter quality in arable and pastoral soils in New Zealand. Soil Biology and Biochemistry, 32(2): 211-219.

Huang L, Wang C Y, Tan W F, et al. 2010. Distribution of organic matter in aggregates of eroded Ultisols, Central China. Soil and Tillage Research, 108(1-2): 59-67.

Institute of Soil Science, Chinese Academy of Sciences. 1978. Soils in China. Beijing: Science Press. (in Chinese)

Jastrow J D. 1996. Soil aggregate formation and the accrual of particulate and mineral-associated organic matter. Soil Biology and Biochemistry, 28(4-5): 665-676.

Jin X B, Wang S M, Zhou Y K. 2008. Dynamic of organic matter in the heavy fraction after abandonment of cultivated wetlands. Biology and Fertility of Soils, 44(7): 997-1001.

John B, Yamashita T, Ludwig B, et al. 2005. Storage of organic carbon in aggregate and density fractions of silty soils under different types of land use. Geoderma, 128(1-2): 63-79.

Knops J M H, Tilman D. 2000. Dynamics of soil nitrogen and carbon accumulation for 61 years after agricultural abandonment. Ecology, 81(1): 88-98.

Kosmas C, Danalatos N G, Gerontidis St. 2000. The effect of land parameters on vegetation performance and degree of erosion under Mediterranean conditions. Catena, 40(1): 3-17.

Kurganova I, Lopes de Gerenyu V, Six J, et al. 2014. Carbon cost of collective farming collapse in Russia. Global Change Biology, 20(3): 938-947.

Li X G, Li F M, Rengel Z, et al. 2006. Cultivation effects on temporal changes of organic carbon and aggregate stability in desert soils of Hexi Corridor region in China. Soil and Tillage Research, 91(1-2): 22-29.

Linsler D, Geisseler D, Loges R, et al. 2013. Temporal dynamics of soil organic matter composition and aggregate distribution in permanent grassland after a single tillage event in a temperate climate. Soil and Tillage Research, 126: 90-99.

Lützow M V, Kögel-Knabner I, Ekschmitt K, et al. 2006. Stabilization of organic matter in temperate soils: mechanisms and their relevance under different soil conditions: a review. European Journal of Soil Science, 57(4): 426-445.

Manna M C, Swarup A, Wanjari R, et al. 2007. Long-term fertilization, manure and liming effects on soil organic matter and crop yields. Soil and Tillage Research, 94(2): 397-409.

Miwa A, Yukio M, Hiroshi T, et al. 2014. Changes in water stable aggregate and soil carbon accumulation in a no-tillage with weed mulch management site after conversion from conventional management practices. Geoderma, 221-222: 50-60.

Nelson D W, Sommers L E. 1996. Total carbon, organic carbon, and organic matter. In: Sparks D L, Page A L, Helmke P A, et al. Methods of Soil Analysis. Part 3. Chemical Methods. Madison, WI: Soil Science Society of America, 961-1010.

Novara A, La Mantia T, Rühl J, et al. 2014. Dynamics of soil organic carbon pools after agricultural abandonment. Geoderma, 235-236: 191-198.

Onweremadu E U, Onyia V N, Anikwe M A N. 2007. Carbon and nitrogen distribution in water-stable aggregates under two tillage techniques in Fluvisols of Owerri area, southeastern Nigeria. Soil and Tillage Research, 97(2): 195-206.

Prishchepov A V, Radeloff V C, Baumann M, et al. 2012. Effects of institutional changes on land use: agricultural land abandonment during the transition from state-command to market-driven economies in post-Soviet Eastern Europe. Environmental Research Letters, 7(2): 024021, doi:10.1088/1748-9326/7/2/024021.

Puget P, Chenu C, Balesdent J. 2000. Dynamics of soil organic matter associated with particle-size fractions of water-stable aggregates. European Journal of Soil Science, 51(4): 595-605.

Raiesi F. 2012. Soil properties and C dynamics in abandoned and cultivated farmlands in a semi-arid ecosystem. Plant and Soil, 351(1-2): 161-175.

Shang Z H, Cao J J, Guo R Y, et al. 2014. The response of soil organic carbon and nitrogen 10 years after returning cultivated 
alpine steppe to grassland by abandonment or reseeding. Catena, 119: 28-35.

Six J, Elliott E T, Paustian K, et al. 1998. Aggregation and soil organic matter accumulation in cultivated and native grassland soils. Soil Science Society of America Journal, 62(5): 1367-1377.

Six J, Paustian K, Elliott E T, et al. 2000a. Soil structure and organic matter: I. Distribution of aggregate-size classes and aggregate-associated carbon. Soil Science Society of America Journal, 64(2): 681-689.

Six J, Elliott E T, Paustian K. 2000b. Soil structure and organic matter: II. A normalized stability index and the effect of mineralogy. Soil Science Society of America Journal, 64(3): 1042-1049.

Six J, Paustian K. 2014. Aggregate-associated soil organic matter as an ecosystem property and a measurement tool. Soil Biology and Biochemistry, 68: A4-A9.

Spohn M, Giani L. 2011. Impacts of land use change on soil aggregation and aggregate stabilizing compounds as dependent on time. Soil Biology and Biochemistry, 43(5): 1081-1088.

Sui Y Y, Jiao X G, Liu X B, et al. 2012. Water-stable aggregates and their organic carbon distribution after five years of chemical fertilizer and manure treatments on eroded farmland of Chinese Mollisols. Canadian Journal of Soil Science, 92(3): 551-557.

Sun D F, Dawson R, Li B G. 2006. Agricultural causes of desertification risk in Minqin, China. Journal of Environmental Management, 79(4): 348-356.

Tisdall J M, Oades J M. 1982. Organic matter and water-stable aggregates in soils. European Journal of Soil Science, 33(2): 141-163.

Waters A G, Oades J M. 1991. Organic matter in water-stable aggregates. In: Wilson W S. Advances in Soil Organic Matter Research: The Impact on Agriculture and the Environment. Cambridge: The Royal Society of Chemistry, 163-174.

Whalen J K, Chang C. 2002. Macroaggregate characteristics in cultivated soils after 25 annual manure applications. Soil Science Society of America Journal, 66(5): 1637-1647.

Wiesmeier M, Steffens M, Mueller C W, et al. 2012. Aggregate stability and physical protection of soil organic carbon in semi-arid steppe soils. European Journal of Soil Science, 63(1): 22-31.

Yamashita T, Flessa H, John B, et al. 2006. Organic matter in density fractions of water-stable aggregates in silty soils: Effect of land use. Soil Biology and Biochemistry, 38(11): 3222-3234.

Yang H, Li X B. 2000. Cultivated land and food supply in China. Land Use Policy, 17(2): 73-88.

Zagal E, Córdova C, Sohi S P, et al. 2013. Free and intra-aggregate organic matter as indicators of soil quality change in volcanic soils under contrasting crop rotations. Soil Use and Management, 29(4): 531-539.

Zhang Y, Li X B, Song W. 2014. Determinants of cropland abandonment at the parcel, household and village levels in mountain areas of China: A multi-level analysis. Land Use Policy, 41: 186-192.

Zhu B B, Li Z B, Li P, et al. 2010. Soil erodibility, microbial biomass, and physical-chemical property changes during long-term natural vegetation restoration: a case study in the Loess Plateau, China. Ecological Research, 25(3): 531-541. 